\title{
サンダーソニアの花茎の頂端分裂組織の無菌培養による多芽体の形成
}

\author{
藤田 孝 $^{1} \cdot$ 梶川好輝 ${ }^{2} \cdot{\text { 西村あずさ }{ }^{2} \cdot \text { 福井博一 }}^{2}$ \\ 1 雪印乳業株式会社技術企画室 350-1165 埼玉県川越市南台 1-1-2 \\ 2 岐皁大学応用生物科学部 501-1193 岐皁県岐皁市柳戸 1-1
}

\section{Multiple Bud Formation by Aseptically Terminal Floral Apex Culture of Sandersonia aurantiaca Hook.}

\author{
Takashi FUJITA ${ }^{1}$, Yoshiteru KAJIKAWA ${ }^{2}$, Azusa NISHIMURA ${ }^{2}$ and Hirokazu FUKUI ${ }^{2}$ \\ ${ }^{1}$ R\&D Planning Dept., Snow Brand Milk Products Co., Ltd., Kawagoe, Saitama 350-1165 \\ ${ }^{2}$ Faculty of Agriculture, Gifu University, Yanagido, Gifu 501-1193
}

\begin{abstract}
In order to establish efficient vegetative micropropagation of Sandersonia aurantiaca Hook., the effects of plant growth regulators on morphological changes of the terminal floral apex were investigated. All explants cultured on Murashige and Skoog medium supplemented with $0 \mu \mathrm{M}$ NAA and $3.2 \mu \mathrm{M}$ TDZ, $3.2 \mu \mathrm{M}$ NAA and $1 \mu \mathrm{M}$ TDZ, $3.2 \mu \mathrm{M}$ NAA and $3.2 \mu \mathrm{M}$ CPPU, or $3.2 \mu \mathrm{M} \mathrm{NAA}$ and $3.2 \mu \mathrm{M}$ TDZ formed multiple buds. The multiple buds consisted of minute adventitious buds, and divided multiple buds proliferated by subculturing on the same component medium. Some multiple buds had elongated shoots, and a miniature tuber was formed at the base of the shoot. These results indicated that Sandersonia aurantiaca was rapidly micropropagated by terminal floral apex culture on four media.
\end{abstract}

Keywords: CPPU, micropropagation, shoot, TDZ, tuber

\begin{abstract}
緒言
サンダーソニア (Sandersonia aurantiaca Hook.) は, 主に 切花として利用されるユリ科の球根花きである. その球根の 養成は主として実生からの育成によって行われており, 効率 的な栄養繁殖法は確立されていない. 近年, サンダーソニア の黄色の花色変異個体が作出されたが ${ }^{1)}$, 分球による繁殖 は増殖率が 2 倍程度であるのに加えて分球後の腐敗等の原 因から, 突然変異個体の出現から切花販売までに 5 年以上 を要し, 効率的な急速栄養繁殖法の開発が望まれている.

一般に球根植物の大量増殖法として組織培養が用いられ
\end{abstract}

2008 年 1 月 15 日受付

2008 年 8 月 25 日受理

Corresponding author: Hirokazu Fukui (fukui@gifu-u.ac.jp)
ており, サンダーソニアでは肧, 肧珠, 未熟種子, 切断種子な どを使用した組織培養による大量増殖法が検討されてきてい $る^{2-6)}$. 著者らも胚珠組織を用いた球根の大量増殖法につい て検討し ${ }^{7}$, 肧珠組織からの多芽体形成を経た効率的な培 養法を明らかにした. しかし, これらの種子由来の組織を用い た組織培養はクローンの大量増殖ではないため, 突然変異に よって生じた花色変異個体や染色体操作などで得られる優 良形質個体の増殖には適していない. サンダーソニアにおけ るクローン増殖を目的とした組織培養の事例としては, 唯一塊 茎組織を供試材料とした Finnie and van Staden ${ }^{3)}$ の報告が あるが, 高濃度の殺菌剂の使用や殺菌剂の長時間処理が 不可欠で, 殺菌剂の影響や杂菌污染により貴重な母株を失 う恐れがある.

そこで本研究では, サンダーソニアのクローン増殖のための 新たな供試組織として花茎の頂端分裂組織に着目し, 花茎 の頂端分裂組織からの形態形成に及ぼすサイトカイニンの影 
響を検討した

\section{材料および方法}

供試植物体として千葉県山武郡芝山町 丸朝園芸農業 協同組合産のサンダーソニア切花 (切花長は $60 \mathrm{~cm}$ で開花 した小花が5〜6輪着生 ) を4〜5月に花き市場より購入した. 花茎の上部 $5 \mathrm{~cm}$ 程度を切り取り, 中性洗剂で洗浄した後, 70\%エタノールに 30 秒程度浸漬し, クリーンベンチ内の滅菌 水で 3 回すすいだ. 実体顕微鏡下で, 花茎の先端部から $0.8 \sim 1.0 \mathrm{~mm}$ の頂端分裂組織を摘出し, 培地に置床した.

\section{花茎の頂端分裂織の成長に及ぼす成長調節物質の影響}

基本培地として Murashige \& Skoog 培地 ${ }^{8}$ ( 以下 MS 培地 )を用い, 成長調節物質, スクロース $6 \%$ およびゲルライ ト $0.2 \%$ を添加し, pH 5.7 に調節した. 成長調節物質はサイト カイニンとオーキシンを組み合わせて添加した. サイトカイニン として 6-benzylaminopurine (BAP), thidiazuron (TDZ), N-(2-chloro-4-pyridyl)-N'-phenylurea (CPPU) の 3 種類を 用い (シグマアルドリッチジャパン株式会社, 東京), 各々 0, 1.0, 3.2, $10.0 \mu \mathrm{M}$ の濃度で添加した. オーキシンは, $a$-naphthalene acetic acid (NAA) $0,3.2 \mu \mathrm{M}$ の濃度で 添加した.

培地は直径 $24 \mathrm{~mm}$, 長さ $100 \mathrm{~mm}$ の管瓶に $10 \mathrm{ml}$ 分注 し, アルミホイルで栓をした後, オートクレーブを用いて $121^{\circ} \mathrm{C}$, $1.2 \mathrm{~kg} \mathrm{~cm}^{-2}$ の条件下で 15 分間加熱滅菌した. 培養条件 は, $25 \pm 1^{\circ} \mathrm{C}, 3000 \mathrm{~lx}, 16$ 時間日長とし, 12 週間培養した後 に調査を行った. 反復個体数は $11 \sim 12$ とした.

茎頂培養 12 週間後に初代培養と同組成の培地を用いて 継代培養を行った. 培養容器は直径 $50 \mathrm{~mm}$, 長さ $100 \mathrm{~mm}$ の培養瓶を用い, これに培地を $40 \mathrm{ml}$ 分注し, 半透明のプラ スチックキャップをした後, $121^{\circ} \mathrm{C}, 1.2 \mathrm{~kg} \mathrm{~cm}^{-2}$ の条件下で 15 分間加熱滅菌した. 培養組織の継代は, 初代培養で形成さ れた培養組織をそのまま取り出して継代培養培地に移植し た. 培養条件は $25 \pm 1{ }^{\circ} \mathrm{C}, 3000 \mathrm{~lx}, 16$ 時間日長とし, 12 週 間後に調査を行った。

\section{結 果}

花茎から摘出した頂端分裂組織の培養にあたって, 予備 的に有効塩素 1\%の次亜塩素酸ナトリウム溶液を用いて花茎 の茎端部を殺菌して培養を行った。しか, 茎端部の花茎が 細く未展開の葉原基数が少ないため, 次亜塩素酸ナリリウム 溶液による頂端分裂組織に対する薬害が激しく, ほとんどの 頂端分裂組織が培養初期に枯死した. そこで次亜塩素酸ナ トリウム濃度を順次低下させて, 頂端分裂組織への薬害およ
び䧱菌污染の影響をみた結果, 茎端部を中性洗剂で良く洗 浄した後, $70 \%$ エタノールで 30 秒程度すすぐ方法でも雑菌 污染がほとんど発生せず, 培養後に頂端分裂組織の生育が 認められた. したがって, 本研究では殺菌剂を用いることなく 中性洗剤と $70 \%$ エタールで花茎の茥端部を洗浄し, 無菌的 に頂端分裂組織を摘出して培養した.

花茎の頂端分裂組織の成長に及ぼす成長調節物質の影響

初代培養 12 週後のシュート伸長, 多芽体形成, 褐変度に 及ぼす成長調節物質の影響を Table 1 に示した. Table 1 の 上段には各成長調節物質を組み合わせて添加した培地区で の形質值を示し, 下段にはオーキシン (NAA) とサイトカイニン (BAP, TDZ, CPPU) の分散分析による主要因効果を示し た. シュート伸長個体率は, 主要因効果において有意とは言 えなかったものの, BAP 濃度が高くなるに従って大きくなる傾 向を示し, シュートの伸長は BAP の添加によって促進された. 特に NAA $3.2 \mu \mathrm{M}$ と BAP $10.0 \mu \mathrm{M}$ を組み合わせた培地区 では $45.5 \%$ と著しく高いシュート伸長個体率を示し, 約半数の 個体でシュート伸長が認められた. またCPPUでは, CPPU $3.2 \mu \mathrm{M}$ と NAA $3.2 \mu \mathrm{M}$ とを組み合わせた培地区において 33.3\%の個体でシュート伸長が認められた.

多芽体の形成はNAAの添加によって促進され, NAA 3.2 $\mu \mathrm{M}$ の主要因効果に示されるように $34.6 \%$ の個体で多芽体 の形成が認められた. 多芽体の形成に及ぼすサイトカイニン の主要因効果はサイトカイニンの種類によって大きく変化し, BAPでは $1.0 \mu \mathrm{M}$ 添加区で高く, TDZ および $\mathrm{CPPU}$ 添加区 ではいずれも $3.2 \mu \mathrm{M}$ 添加区で $55.9 \%, 66.2 \%$ 半数以上の 個体で多芽体の形成が確認された. 各培地区における多芽 体の形成率を見ると, NAA $3.2 \mu \mathrm{M}$ と TDZ $3.2 \mu \mathrm{M}$ を組み合 わせた培地区では $81.8 \%$ が多芽体を形成し, 同様に NAA $3.2 \mu \mathrm{M}$ と CPPU $3.2 \mu \mathrm{M}$ を組み合わせた培地区でも $77.8 \%$ の多芽体形成個体率を示した.

培養組織の褐変度についてみると, NAAの添加によって 褐変が抑制された. また, BAPの主要因効果では添加した 濃度が高くなるに従って明らかに褐変度が低下し, BAP の褐 変抑制効果が認められた. TDZ および CPPU では $1.0 \mu \mathrm{M}$ と $3.2 \mu \mathrm{M}$ で褐変度が低い值を示した. 培地区を個別にみる と, NAA $0.0 \mu \mathrm{M}$ と TDZ $10.0 \mu \mathrm{M}$ を組み合わせた区と NAA $0.0 \mu \mathrm{M}$ でサイトカイニン無添加の区ですべての個体が褐変 枯死した. また, NAA $3.2 \mu \mathrm{M}$ と BAP $10.0 \mu \mathrm{M}$ を組み合わせ た区と NAA $3.2 \mu \mathrm{M}$ と CPPU $3.2 \mu \mathrm{M}$ を組み合わせた区では ほとんどの個体で褐変が認められなかった。

初代培養 12 週間後の調查形質間の関係をみた結果 (Table 2), 展葉数とシュート伸長個体率との間には高い正の 相関が認められ, 褐変度と展葉数, シュート伸長個体率拉よ び多芽体形成個体率との間には負の相関が涊められた. ま 
Table 1 Effect of different combination of NAA and cytokinins on morphological changes from terminal floral apex of S.aurantiaca.

\begin{tabular}{|c|c|c|c|c|c|c|c|c|c|}
\hline \multirow[t]{2}{*}{ NAA } & \multicolumn{3}{|c|}{ Cytokinin } & \multicolumn{3}{|c|}{ Primary culture ( 12 weeks) } & \multicolumn{3}{|c|}{ Subculture (12 weeks) } \\
\hline & BAP & $\mathrm{TDZ}$ & 4CPPU & $\begin{array}{l}\text { Explants } \\
\text { elongated } \\
\text { shoot (\%) }\end{array}$ & $\begin{array}{c}\text { Explants } \\
\text { formed } \\
\text { multiple } \\
\text { buds (\%) }\end{array}$ & Browning* & $\begin{array}{l}\text { Explants } \\
\text { elongated } \\
\text { shoot (\%) }\end{array}$ & $\begin{array}{c}\text { Explants } \\
\text { formed } \\
\text { multiple } \\
\text { buds (\%) }\end{array}$ & Browning* \\
\hline 0.0 & 0.0 & 0.0 & 0.0 & 0.0 & 0.0 & 5.0 & 0.0 & 0.0 & 5.0 \\
\hline 0.0 & 1.0 & 0.0 & 0.0 & 8.3 & 0.0 & 3.5 & 14.3 & 0.0 & 4.6 \\
\hline 0.0 & 3.2 & 0.0 & 0.0 & 18.2 & 0.0 & 2.6 & 0.0 & 0.0 & 4.3 \\
\hline 0.0 & 10.0 & 0.0 & 0.0 & 27.3 & 9.1 & 1.2 & 50.0 & 0.0 & 3.9 \\
\hline 0.0 & 0.0 & 1.0 & 0.0 & 18.2 & 9.1 & 2.9 & 0.0 & 42.9 & 5.0 \\
\hline 0.0 & 0.0 & 3.2 & 0.0 & 0.0 & 30.0 & 3.4 & 0.0 & 100.0 & 1.0 \\
\hline 0.0 & 0.0 & 10.0 & 0.0 & 0.0 & 0.0 & 5.0 & 0.0 & 0.0 & 5.0 \\
\hline 0.0 & 0.0 & 0.0 & 1.0 & 8.3 & 8.3 & 3.4 & 0.0 & 0.0 & 5.0 \\
\hline 0.0 & 0.0 & 0.0 & 3.2 & 0.0 & 54.5 & 2.8 & 0.0 & 80.0 & 2.0 \\
\hline 0.0 & 0.0 & 0.0 & 10.0 & 0.0 & 25.0 & 4.0 & 66.7 & 66.7 & 2.3 \\
\hline 3.2 & 0.0 & 0.0 & 0.0 & 0.0 & 0.0 & 4.3 & 0.0 & 0.0 & 5.0 \\
\hline 3.2 & 1.0 & 0.0 & 0.0 & 0.0 & 63.6 & 1.5 & 0.0 & 0.0 & 5.0 \\
\hline 3.2 & 3.2 & 0.0 & 0.0 & 11.1 & 22.2 & 0.6 & 14.3 & 0.0 & 3.9 \\
\hline 3.2 & 10.0 & 0.0 & 0.0 & 45.5 & 0.0 & 0.1 & 50.0 & 0.0 & 1.0 \\
\hline 3.2 & 0.0 & 1.0 & 0.0 & 10.0 & 50.0 & 0.6 & 28.6 & 100.0 & 2.0 \\
\hline 3.2 & 0.0 & 3.2 & 0.0 & 0.0 & 81.8 & 1.1 & 11.1 & 100.0 & 1.3 \\
\hline 3.2 & 0.0 & 10.0 & 0.0 & 0.0 & 10.0 & 3.5 & 0.0 & 20.0 & 4.6 \\
\hline 3.2 & 0.0 & 0.0 & 1.0 & 9.1 & 18.2 & 1.3 & 0.0 & 37.5 & 4.1 \\
\hline 3.2 & 0.0 & 0.0 & 3.2 & 33.3 & 77.8 & 0.3 & 44.4 & 100.0 & 1.3 \\
\hline 3.2 & 0.0 & 0.0 & 10.0 & 0.0 & 22.2 & 3.6 & 0.0 & 50.0 & 3.5 \\
\hline \multicolumn{4}{|c|}{ Total average } & 9.5 & 24.1 & 2.5 & 14.0 & 34.9 & 3.5 \\
\hline \multicolumn{10}{|c|}{ Effect of principle factor by ANOVA** } \\
\hline 0 & & & & $8.0 \mathrm{a}$ & $13.6 \mathrm{a}$ & $3.4 \mathrm{~b}$ & $13.1 \mathrm{a}$ & $29.0 \mathrm{a}$ & $3.8 \mathrm{a}$ \\
\hline 3.2 & & & & $10.9 \mathrm{a}$ & $34.6 \mathrm{~b}$ & $1.7 \mathrm{a}$ & $14.8 \mathrm{a}$ & $40.8 \mathrm{a}$ & $3.2 \mathrm{a}$ \\
\hline & 0 & & & $0.0 \mathrm{a}$ & $0.0 \mathrm{a}$ & $4.6 \mathrm{c}$ & $0.0 \mathrm{a}$ & $0.0 \mathrm{a}$ & $5.0 \mathrm{a}$ \\
\hline & 1.0 & & & $4.2 \mathrm{a}$ & $31.8 \mathrm{a}$ & $2.5 \mathrm{~b}$ & $7.1 \mathrm{a}$ & $0.0 \mathrm{a}$ & $4.8 \mathrm{a}$ \\
\hline & 3.2 & & & $14.6 \mathrm{a}$ & $11.1 \mathrm{a}$ & $1.6 \mathrm{ab}$ & $7.1 \mathrm{a}$ & $0.0 \mathrm{a}$ & $4.1 \mathrm{a}$ \\
\hline & 10.0 & & & $36.4 \mathrm{a}$ & $4.5 \mathrm{a}$ & $0.6 \mathrm{a}$ & $50.0 \mathrm{a}$ & $0.0 \mathrm{a}$ & $2.4 \mathrm{a}$ \\
\hline & & 0 & & $0.0 \mathrm{a}$ & $0.0 \mathrm{a}$ & $4.6 \mathrm{~b}$ & $0.0 \mathrm{a}$ & $0.0 \mathrm{a}$ & $5.0 \mathrm{a}$ \\
\hline & & 1.0 & & $14.1 \mathrm{~b}$ & $29.5 \mathrm{a}$ & $1.8 \mathrm{a}$ & $14.3 \mathrm{a}$ & $71.4 \mathrm{a}$ & $3.5 \mathrm{a}$ \\
\hline & & 3.2 & & $0.0 \mathrm{a}$ & 55.9 a & $2.2 \mathrm{a}$ & $5.6 \mathrm{a}$ & $100.0 \mathrm{a}$ & $1.2 \mathrm{a}$ \\
\hline & & 10.0 & & $0.0 \mathrm{a}$ & $5.0 \mathrm{a}$ & $4.3 \mathrm{~b}$ & $0.0 \mathrm{a}$ & $10.0 \mathrm{a}$ & $4.8 \mathrm{a}$ \\
\hline & & & 0 & $0.0 \mathrm{a}$ & $0.0 \mathrm{a}$ & $4.6 \mathrm{~b}$ & $0.0 \mathrm{a}$ & $0.0 \mathrm{a}$ & $5.0 \mathrm{a}$ \\
\hline & & & 1.0 & $8.7 \mathrm{a}$ & $13.3 \mathrm{a}$ & $2.3 \mathrm{a}$ & $0.0 \mathrm{a}$ & $18.8 \mathrm{a}$ & $4.6 \mathrm{a}$ \\
\hline & & & 3.2 & $16.7 \mathrm{a}$ & $66.2 \mathrm{~b}$ & $1.6 \mathrm{a}$ & $22.2 \mathrm{a}$ & $90.0 \mathrm{a}$ & $1.7 \mathrm{a}$ \\
\hline & & & 10.0 & $0.0 \mathrm{a}$ & $23.6 \mathrm{a}$ & $3.8 \mathrm{~b}$ & $33.3 \mathrm{a}$ & $58.3 \mathrm{a}$ & $2.9 \mathrm{a}$ \\
\hline
\end{tabular}

*: $0=$ no browning was observed, $1=$ a part of the explant was slightly brown, $2=$ a part of the explant was brown, $3=$ $50 \%$ of the explant was brown, $4=75 \%$ of the explant was brown, $5=$ the explant was completely brown and died. $* *$ : Effect of principle factor was calculated by average for values on several concentrations in plant growth regulator. Means within a column with the same letter are not significantly different at $p<0.01$

た，多芽体形成は展葉やシュート伸長との間で相関はみられ

ず, 多芽体の形成は独立した形態形成であることが明らかと なった.

初代培養 12 週間後に同じ組成の培地に継代培養し, さら に 12 週間培養した後の形態形成に及ぼす成長調節物質の 影響をみると (Table 1), 初代培養でシュート伸長がみられた
培地区では継代培養においても同様にシュートの伸長が継続 してみられ, NAA $0.0 \mu \mathrm{M}$ とCPPU $10.0 \mu \mathrm{M}$ の培養区を除 いて, 両培養期間におけるシュート伸長個体率間で高い相関 が認められた。

多芽体形成個体率についてみると, 初代培養ではわずか に多芽体形成が認められた BAP 添加区では多芽体が全く 
Table 2 Correlations between different characters in terminal floral apex cultures of $S$. aurantiaca after 12 weeks of culture.

\begin{tabular}{lccc}
\hline \hline & $\begin{array}{c}\text { Explants } \\
\text { elongated } \\
\text { shoot (\%) }\end{array}$ & $\begin{array}{c}\text { Explants formed } \\
\text { multiple buds } \\
(\%)\end{array}$ & Browning \\
\hline $\begin{array}{l}\text { Number of leaves } \\
\text { Explants elong }\end{array}$ & $0.752^{* *}$ & 0.299 & $-0.870^{* *}$ \\
$\begin{array}{l}\text { ated shoot (\%) } \\
\begin{array}{l}\text { Explants formed } \\
\text { multiple buds (\%) }\end{array}\end{array}$ & - & -0.086 & $-0.642^{* *}$ \\
\hline
\end{tabular}

**: significantly different at $P=0.01$

*: significantly different at $P=0.05$
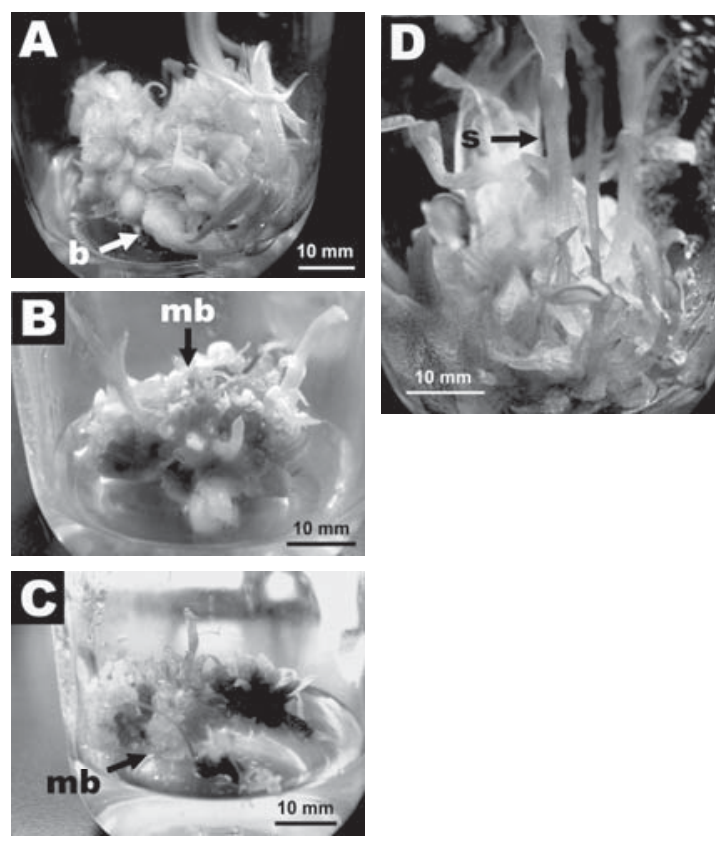

Fig. 1 Multiple buds formed after subculture for 12 weeks following primary culture for 12 weeks.

A: NAA $3.2 \mu \mathrm{M}+$ TDZ $1.0 \mu \mathrm{M}$

B: NAA $3.2 \mu \mathrm{M}+$ CPPU $1.0 \mu \mathrm{M}$

C: NAA $3.2 \mu \mathrm{M}+$ CPPU $3.2 \mu \mathrm{M}$

D: NAA $3.2 \mu \mathrm{M}+\mathrm{CPPU} 3.2 \mu \mathrm{M}$

b: bulb

mb: multiple buds

s: shoot

みられなくなったのに対して, TDZ や CPPU 添加区では継 代培養によって多芽体の形成個体率が高くなり, TDZ および CPPU の多芽体形成促進効果が認められた. なかでも NAA $3.2 \mu \mathrm{M}$ を同時に添加した区では多芽体の形成が著しく促 進された．培地区を個別にみると, NAA $0.0 \mu \mathrm{M}$ と TDZ 3.2 $\mu \mathrm{M}$, NAA $3.2 \mu \mathrm{M}$ と TDZ $1.0 \mu \mathrm{M}$, NAA $3.2 \mu \mathrm{M}$ とTDZ3.2 $\mu \mathrm{M}$, NAA $3.2 \mu \mathrm{M}$ と CPPU $3.2 \mu \mathrm{M}$ を組み合わせた区では
すべての個体で多芽体が形成された.

継代培養 12 週間後の組織の褐変は, サイトカイニン無添 加区および NAA $0.0 \mu \mathrm{M}$ と TDZ $1.0 \mu \mathrm{M}$, NAA $0.0 \mu \mathrm{M}$ と TDZ $10.0 \mu \mathrm{M}$, NAA $0.0 \mu \mathrm{M}$ と CPPU $1.0 \mu \mathrm{M}$, NAA $3.2 \mu \mathrm{M}$ と BAP $1.0 \mu \mathrm{M}$ を組み合わせた区ですべての個体が褐変枯 死した. TDZと CPPUについてみると, $3.2 \mu \mathrm{M}$ 区において 褐変度が低い傾向があり, 特に NAA $3.2 \mu \mathrm{M}$ を同時に添加 した場合には褐変がわずかであった.

継代培養 12 週間後に形成された多芽体を Fig. 1 に示し た. 形成された多芽体は初代培養において肥大した茥頂組 織から形成され, 新たな不定芽を次々と形成しながら組織が 肥大し, 多芽体を形成した. 多芽体からはシュートの伸長が みられるとともに, 伸長したシュートの基部には子球の形成が 観察された. 多芽体のなかには多数の微細な不定芽によって 構成されているものから, 多数のシュートの伸長を伴うものまで あり, 微細な不定芽によって構成されている多芽体はそれを 分割することで, 多芽体が増殖した. また子球を形成したもの については, 多芽体から子球を分割することで培養器から取 り出して容易に栽培することが可能であった.

考察

サンダーソニアの通常の栄養繁殖では, 1 作につき 1 個の 塊茥から 2 個体分の塊茥しか形成されない. このような増殖 効率の低い作物に関しては, 組織培養技術を利用したクロー ン増殖が試みられており, チューリップ 9), スイセン ${ }^{10)}$, グロリ オーサ ${ }^{11,12)}$, ギミア・リリー ${ }^{13)}$ などの報告がある. 一般に, ク ローン増殖は遺伝的安定性の高い茥頂成長点を用いた茎頂 培養が行われており, 茎端部や腋芽に茎頂成長点を持つ栄 養成長器官のシュートが供試材料として用いられている. しか し, サンダーソニアは栄養成長器官としてのシュートを持たず, 厳密な意味での茥頂成長点は球根から伸長した花茎の基 部に形成される二又状の球根の先端のみに存在し, Finnie and van Staden ${ }^{3)}$ はこの茥頂成長点を用いて培養を行ってい る. しかし, 球根先端部の茎頂成長点は地下部で形成され るため, 殺菌が極めて困難である.

サンダーソニアの花茥は生殖器官であり, 花茥の先端の頂 端分裂組織が新たな葉原基を分化しながら伸長し, その葉 液部に小花を形成する. 花茥の頂端分裂組織は厳密な意味 での茥頂成長点ではないものの, 無限伸長を行うことから, 栄 養成長器官の茎頂成長点に近い細胞分裂能力を持つと考 え, 切花として出荷されている花茥を供試材料として培養を 行った. 花茥の頂端分裂組織を用いたクローン増殖の事例と してはバナナの報告 ${ }^{14)}$ があるが, これ以外では事例はない. 本研究結果は栄養成長器官としてのシュートを形成しない宿 
根性切花などに広く適用できると考える.

一般に茥頂培養を行う場合には, 茥頂成長点の in vitro への導入にあたって次亜塩素酸ナトリウム溶液などの殺菌剂 を用いた表面殺菌が不可欠である. しかし, サンダーソニア は花茎が細く, 殺菌剤の薬害が顕著に発生し, 頂端分裂組 織の培養が困難であった. そこで, 次亜塩素酸ナトリウムの 濃度を低下させて頂端分裂組織の摘出および培地への置床 を試みた結果, 殺菌剂を使用することなく適切な洗浄操作を 経ることによって無殺菌で頂端分裂組織が摘出でき, 培養が 可能であった. これは, 頂端分裂組織の周辺が新たに分化し た葉原基で覆われているため無菌状態が維持されていること によるもので, サンダーソニアのような花茥が細い植物におい ては次亜塩素酸ナトリウムによる殺菌を行うことなく頂端分裂 組織の培養が可能であることが示唆され, 本研究における培 養前の処理は同様な形態を持つ植物においても適用できると 考える.

サンダーソニアの花茥の頂端分裂組織からの in vitro での 形態形成に及ぼす成長調節物質の影響を検討した結果, 多芽体の形成は CPPU と TDZ の培地への添加によって促 進され，BAPを添加した区では認められなかった. CPPUと TDZ は尿素系サイトカイニンに属し, BAP などのアデニン系サ イトカイニンより高い苗条形成活性を示すといわれており ${ }^{15)}$, 本研究においても TDZ $3.2 \mu \mathrm{M}$ を添加した区では, NAAの 添加の有無にかかわらず, 継代培養 12 週間後にはすべて の個体で多芽体が形成され, CPPU $3.2 \mu \mathrm{M}$ 添加区におい ても著しく高い多芽体形成率を示した. 尿素系サイトカイニン がプリン系サイトカイニンに比べて高い不定芽形成を示し, 多 芽体の形成を促進した事例としては, Mesembryanthemum crystallinum $^{16)}$, Paspalum scrobiculatum ${ }^{17)}$, Phaseolus angularis $^{18)}$ などがある. 本研究における多芽体形成率と褐 変度を比較すると, 両者の間に高い負の相関がみられ $\left(R^{2}=\right.$ 0.57) た. TDZ や CPPU の培地への添加によって多芽体の 形成や増殖が促され，このことが組織の褐変を抑制したもの と考える.

サンダーソニアと比較的近縁な植物にグロリオーサがあ り, Finnie and van Staden ${ }^{3)}$ はサンダーソニアとグロリオー サの組織培養における反応は非常に類似していると報告 している. グロリオーサの茥頂培養については Sivakumar and Krishnamurthy ${ }^{12)}$ の報告や島崎ら ${ }^{19)}$ の報告があり, Sivakumar and Krishnamurthy ${ }^{12)}$ は, 2ip と kinetin を同時 に添加することによって成長の速い多芽体が形成されたと報 告している. また, 島崎ら ${ }^{19)}$ は開花株側枝の茥頂組織の培 養を行い, BAP に比べて TDZ は生存個体率が高く, シュー 卜形成率や塊茎形成率も高かったと報告している. 本研究で 明らかとなった培養条件は, サンダーソニアのみならずグロリ
オーサの大量増殖法の開発にも有益な知見を与えると考える.

本研究の 12 週間の継代培養の結果, NAA $0.0 \mu \mathrm{M}$ と TDZ $3.2 \mu \mathrm{M}$, NAA $3.2 \mu \mathrm{M}$ と TDZ $1.0 \mu \mathrm{M}$, NAA $3.2 \mu \mathrm{M}$ と TDZ $3.2 \mu \mathrm{M}$, NAA $3.2 \mu \mathrm{M}$ と CPPU $3.2 \mu \mathrm{M}$ を組み合わせ た 4 培地区においてすべての個体で多芽体が形成され，な かでも NAA $3.2 \mu \mathrm{M}$ と TDZ $3.2 \mu \mathrm{M}$ および CPPU $3.2 \mu \mathrm{M}$ を 組み合わせた培地区では褐変度も低かったことから, サンダ ーソニアの花茥の頂端分裂組織をこれらの培地区で培養す ることによって, これまで困難とされたサンダーソニアのクロー ン増殖が可能となると判断した。

\section{摘 要}

サンダーソニアのクローン増殖を目的として, 生殖成長器 官である花茎の頂端分裂組織からの形態形成に及ぼすサイ トカイニンの影響を検討した. NAA とサイトカイニン (BAP, TDZ, あるいは CPPU) を組み合わせて添加した培地で培養 した結果, NAA $0.0 \mu \mathrm{M}$ と TDZ $3.2 \mu \mathrm{M}$, NAA $3.2 \mu \mathrm{M}$ と TDZ $1.0 \mu \mathrm{M}$, NAA $3.2 \mu \mathrm{M}$ と TDZ $3.2 \mu \mathrm{M}$, NAA $3.2 \mu \mathrm{M}$ とCPPU $3.2 \mu \mathrm{M}$ を組み合わせた 4 培地区において, 供試したすべて の花茎の頂端分裂組織から多芽体が形成された. 多芽体の なかには多数の微細な不定芽によって構成されているものが あり, それを分割することで, 多芽体が増殖した. 多芽体か らはシュートの伸長がみられるとともに, 伸長したシュートの基 部には子球の形成が観察されたことから, サンダーソニアの 花茎の頂端分裂組織をこれらの培地区で培養することによっ て, サンダーソニアのクローン増殖が可能となると判断された.

\section{引用文献}

1) Nielsen KM, Lewis DH, Morgan ER. Characterization of carotenoid pigments and their biosynthesis in two yellow flowered lines of Sandersonia aurantiaca (Hook.). Euphytica 130: 25-34. 2003.

2) Finnie JF, van Staden J. In vitro propagation of Sandersonia and Gloriosa. Plant Cell Tissue Org. Cult. 19: 151-158. 1989.

3) Finnie JF, van Staden J. Sandersonia aurantiaca Hook. (Christmas Bells): Micropropagation and in vitro production of colchitine. In: Biotechnology in agriculture and forestry, vol 37. Medicinal and aromatic plants 9, ed. Bajaj YPS. Springer-Verlag, Berlin, Heidelberg. 355-369. 1996.

4）服部澄子, 福井博一, 中村三夫. サンダーソニアの胚培 養及び培養中の子球の生育様式について. 園学要旨. 61 (別 2):468-469. 1992.

5）居城幸夫, 永井愛, 尾形亮輔. サンダーソニアの胚培養 における光条件とショ糖濃度の影響と, 継代後の子球形 
成に及ぼすポリエチレングリコール (PEG) の影響. 園学 要旨. 66 (別 1) : 508-509. 1997.

6) 澤 完, 小林加奈. サンダーソニア切断種子, 未熟 種子, 並びに, 胚培養について. 園学要旨. 60 (別 2) : 520-521. 1991.

7）藤田 孝, 杉村謙一郎, 門脇知子, 畑本 均, 高橋哲 也, 久保木篤, 大川恵子, 不破規智, 桜井聡子, 福井 博一. サンダーソニアの肧珠培養による多芽体の形成. 植物環境工学 18: 123-129. 2006.

8) Murashige T, Skoog F. A revised medium for rapid growth and bioassays with tobacco tissue cultures. Physiol. Plant. 15: 473-497. 1962.

9) Podwyszynska M. Improvement of bulb formation in micropropagated tulips by treatment with NAA and pacrobutrazol or ancymidole. Acta Horticulturae 725: 679-684. 2006.

10) Sharma YD, Kanwar SB. Studies on micropropagation of tulips and daffodils. Acta Horticulturae 624: 535-540. 2003.

11) Jadhav SY, Hegde BA. Somatic embryogenesis and plant regeneration in Gloriosa L. Indian Journal of Experimental Biology 39: 943-946. 2001.

12) Sivakumar G, Krishnamurthy KV. Micropropagation of Gloriosa superba L., an endangered species of Asia and Africa. Curr. Sci. 78: 30-32. 2000.

13) Dimech AM, Cross R, Ford R, Taylor WJ. Micropropagation of Gymea Lily (Doryanthes excelsa Corrêa) from New South Wales, Australia. Plant Cell, Tissue and Organ Culture. 88: 157-165. 2007.
14) Cronauer SS, Krikorian $\mathrm{AD}$. Reinitiation of vegetative growth from aseptically cultured terminal floral apex of banana. Amer. J. Bot. 72: 1598-1601. 1985.

15) 黒崎文也, 首藤紘一, 岡本敏彦, 磯谷 遙. 尿素系 サイトカイニンとアデニン系サイトカイニンの作用点につい て 植物化学調節研究会研究発表記録集 No. 昭和 55 年度 (19801003) 31-32. 1980.

16) Sunagawa H, Agarie S, Umemoto M, Makishi Y, Nose A. Effect of urea-type cytokinins on the adventitious shoots regeneration from cotyledonary node explant in the common ice plant, Mesembryanthemum crystallinum. Plant Prod. Sci. 10: 47-56. 2007.

17) Rashid VA. Induction of multiple shoots by thidiazuron from caryopsis cultures of minor millet (Paspalum scrobiculatum L.) and its effect on the regeneration of embryogenic callus cultures. Plant Cell Rep. 21: 9-13 2002.

18) Mohamed SV, Sung JM, Jeng TL, Wang CS. Organogenesis of Phaseolus angularis L.: high efficiency of adventitious shoot regeneration from etiolated seedlings in the presence of N6benzylaminopurine and thidiazuron. Plant Cell Tissue Organ Culture 86: 187-199. 2006.

19）島崎一彦, 鈴木 悟, 福元康文. グロリオーサ (Gloriosa superba) の開花中の株から採取した側枝 の茎頂および茎切片の in vitro での器官形成に及ぼ すチジアズロン (TDZ) の影響. 生物環境調節. 38 : 207-210. 2000. 